\title{
Defining entrepreneurial success to improve guidance services: a study with a comprehensive database from Andalusia
}

\author{
Manuel Chaves-Maza and Eugenio M. Fedriani* (D)
}

*Correspondence:

efedmar@upo.es

Universidad Pablo de

Olavide, Ctra. de Utrera, km 1,

41013 Sevilla, Spain

\begin{abstract}
The aim of this paper is to assess the level of success achieved by entrepreneurs. The concept of success has many subjective facets, and it needs to be evaluated to reach other higher objectives, such as improving support systems for entrepreneurs. The usual pre-existing focuses for the evaluation of business performance are analysed and adapted. Based on a real case, the most relevant variables for detecting success are studied and an algorithmic process (based on decision trees) is established to ascertain whether an entrepreneur has achieved success. The data refers to entrepreneurs from Andalusia, the European region with the highest unemployment rates and where support for entrepreneurship is on the agenda of all political parties. The model specifies a minimal set of variables to evaluate success in each case. Subsequently, a simple set of 29 questions is also offered, serving to classify most entrepreneurs (over $98 \%$ of 2221 individuals in the case analysed) by their level of success. An objective procedure to measure the success of entrepreneurs is given. Such method is based on artificial intelligence and on three focuses: positioning, expectations and evolution. Both the variables used in this case and the 29 questions necessary to classify the entrepreneurs by their level of success are explicitly provided.
\end{abstract}

Keywords: Entrepreneurship, Achievement, Assessment, Decision trees, Classification

\section{Introduction}

Entrepreneurship has always existed, though it seems to have become particularly relevant in recent times, perhaps due to the latest economic crisis (Chadha \& Dutta, 2020). Society asks for entrepreneurship, above all, of those who do not find their place in the labour market. Entrepreneurs, for their part, dream of finding a good idea and designing a business model that will improve their situation. This desire, predefined or not (Hovig et al., 2018), underlies part of the definition of the 'business success of the entrepreneur'.

It appears obvious that success is a subjective concept (Al Issa, 2021), and so it cannot have a universally valid quantitative definition. However, it is only by means of a reasonable definition of success that it is possible to perform a rigorous analysis of the factors that produce or facilitate it, and so it makes sense to use mathematical and statistical party material in this article are included in the article's Creative Commons licence, unless indicated otherwise in a credit line to the material. If material is not included in the article's Creative Commons licence and your intended use is not permitted by statutory regulation or exceeds the permitted use, you will need to obtain permission directly from the copyright holder. To view a copy of this licence, visit http:// creativecommons.org/licenses/by/4.0/. 
tools to attempt to understand success on the basis of objective information taken from cases of entrepreneurship.

One of the first consequences of the quantitative approach is that there is no single level of success. There could be up to a different level for each entrepreneurship project, but that would not be useful; to allow an accurate ranking, we will minimize the number of levels of success. The opposite pole to successful entrepreneurship is failure, understood as the failure of the entrepreneur's business idea to survive. In view of the complexity of the concept being evaluated, it would appear useful to add, at least, a third category so as to distinguish between successful entrepreneurs and entrepreneurs who simply survive. That third category could be called: moderate success or survival (without proper success); it will be referred to as "survival" from now on. Thus, the simplest classification that would be generated goes as follows: success, survival, and failure. In fact, we will adopt this three-level classification.

The aim of entrepreneur support institutions should be to minimise failure, if possible, while maximising success. These institutions should take into account the idea of success held by each individual entrepreneur and they should be able to evaluate their positioning with respect to this goal at all times (Zhai et al., 2019). Recognition of success is, therefore, fundamental to offer personalised support and advice to the entrepreneur. We must also admit that society benefits from successful entrepreneurs (Bazan et al., 2020; Khalilov \& Yi, 2021), so, we cannot just settle for minimizing failure.

From another point of view, to evaluate the support services offered to entrepreneurs, it is necessary to know whether or not the users of these services have achieved their desired success (Kiyabo \& Isaga, 2020). For example, in Morris et al. (2005), the success of the entrepreneur was implicitly identified with the amount of money generated. However, the intention here is not exactly to measure the performance of an entrepreneur; it implies something more subjective which cannot be measured through economic variables alone (Maehr \& Sjogren, 1971). It does involve the level of effectiveness of the business, but not only that.

Neither the methodology nor the structure of this paper is exactly the usual in the field. As business success is a concept that comprises many definitions and interpretations, the next section of this article is a bibliographic review of the variables directly related to business success. A description is then given of a procedure which offers a composite definition of success based on decision trees, and on three focuses: positioning, expectations and evolution. Both the variables and the 29 questions necessary to classify the entrepreneurs by their level of success are explicitly provided. The validity of the model designed is checked using the data of the Andalusian entrepreneurs who are used to illustrate the model. The article ends with the presentation and discussion of the most relevant results and conclusions.

\section{Literature review}

Future entrepreneurs may or may not enjoy the support of a public institution (Alkahtani et al., 2020; Woods et al., 2020). In all events, to take decisions during the early years of a new company's existence, it is crucial to understand, at least, the most important factors which determine survival, growth and success (Gómez-Villanueva, 2008). For this reason, experts have analysed the success or failure of entrepreneurs from many 
perspectives, for example: would the beneficiary of that success be the entrepreneur, taking into account the personal and professional satisfaction they enjoy? (Khan et al., 2021; Maehr \& Sjogren, 1971) Or would it be the project itself, as a business, considering its net return? Or would it be the employees, with the professional benefits and repercussion that it produces? Or perhaps society, thanks to the economic development and the low impact on resources produced by the activity? (Bazan et al., 2020; Claire, 2012). Logically, very different indicators have also been used to measure that benefit (Harms et al., 2007). However, the greater part of research into this type of evaluation focuses on different ways of measuring the results in companies, without specifying the particular case of the entrepreneurs.

Thus, Gómez-Gómez et al. (2016) point to the main problems in evaluating business excellence: many dimensions are involved, and each dimension can refer to different variables, each variable can be measured on different scales and the data on different companies is rarely comparable. As if this were little enough, determining the minimum level of excellence for each dimension is a subjective process.

Perhaps the most apparently objective dimension is the survival of the company (Audretsch, 1991), but the relationship between survival and success should be analysed carefully (Nikolic et al., 2019), as should the relationship between failure and returns. Though it is true that companies with low returns tends to disappear, depending on the type of company, sector, environment and other factors, this could be understood as part of the life-cycle of the business and it can be taken as natural that the entrepreneur should go on to create another company. That is, there is no purely linear relationship between business returns and the survival of the company created: it may be better to close the company as soon as losses begin to accumulate, sell the business or even declare bankruptcy (Cefis \& Marsili, 2011).

Taking this aspect into account, it can be seen that it is difficult to establish the exact relationship between the phenomenon studied and the dimension analysed. It is even more difficult to find relationships that remain unaltered when the context is changed. For example, newly created businesses suffer a higher percentage rate of 'mortality' than older companies (incidentally, this high rate of disappearance is usually associated with a deficient evaluation of the business plan in the preliminary stages of assistance). Despite this 'failure' and its possible personal and financial consequences, whether or not another attempt is made is a question of culture, and so the lack of survival does not always correspond with the same level of failure (Nikolic et al., 2019).

Many authors even distinguish between company closures due to insolvency and voluntary closures and this can also be reflected by an additional dichotomous variable. However, using official data, it is difficult to distinguish the businesses that have ceased trading from those which have failed. Headd (2003) found that 66 per cent of the businesses which closed were not successful, but the rest closed despite achieving success. The factors that were deduced to be significant for survival were similar to those found in other studies, but those identified for companies that closed (such as being a new company or not having initial capital) could lead to failure or to success despite the closure of the company.

Finally, there remains the difficulty of correctly defining each variable and for those variables to be easily measured. In the previous example, with respect to the dates of 
companies' entering and leaving the market, different alternatives have been considered, in line with the reference literature and depending on whether or not there is access to data on registration or deregistration in the official companies register. The registration or deregistration of the entrepreneur or the workers is usually also considered, with the registration usually being taken as the year prior to the hiring of the first worker in the company and deregistration as the last year. Some also take this data from a sample, from panel data or from official statistics (Strotmann, 2007). Unfortunately, the study of the above variables differs as a result of different characteristics in the country analysed.

We shall now review the efforts to measure the success of companies to attempt to adapt them to the case of entrepreneurs. Broadly speaking, there are different statuses: failure or non-survival, marginal survival and success or high growth (Cooper et al., 1989). In fact, the classification proposed below in this article adopts a similar approach.

Different methodologies are available to address the problem generally and there is no consensus. Thus, Morris et al. (2005) offer groups of key questions to evaluate the success of a company: value creation, the beneficiaries of value creation, competitiveness, positioning, growth plans. Other authors select a sample of successful companies, on the basis of their returns, growth, survival, etc., and another of unsuccessful companies. They then analyse variations and correlations to determine relationships between the different variables studied (Duchesneau \& Gartner, 1990).

In summary, although the literature contains very diverse possibilities, a concept of success is established hereafter which comprises three fundamental focuses: positioning, expectations and evolution. Each of these can be analysed (in all the levels of success or categories set out in this paper) through different variables or characteristics (some totally objective and others not so objective; some quantitative and others qualitative), as described below.

\section{Positioning}

The first focus refers to the competitive position of the entrepreneur with respect to other market agents. In fact, one of the keys to the success of the entrepreneur is the capacity to adjust their projects to adapt to the activities and meet the interests of the rest of the agents active in the same sphere (Brown et al., 2009).

Competitive success or business competitiveness has been defined by many authors (Camisón, 1997; García \& Álvarez, 1996; Kester \& Luerhrman, 1989; Viedma, 1992) as the capacity to generate sustainable competitive advantages to produce goods and services, creating value or to compete with rival companies for the same market niche. Each strategy involves different skills and requirements for success (Porter, 1991). Other definitions consider competitiveness as the capacity to achieve a favourable competitive position, in rivalry with other companies; that will lead to performance superior to that of competitors (Aragón \& Rubio, 2005). Many authors refer here to comparisons with other companies or entrepreneurs who undertake the same type of activity. They hold that the external framework is a constant influence on all the stages of the organisational life cycle and, by extension, on the concept of success, with the moral support network (which is also closely related to the ultimate aim of this research) being the factor most highly valued by entrepreneurs (González, 2003). 
Table 1 Some indicators to measure positioning

\begin{tabular}{|c|c|c|}
\hline Types & Indicators & Authors \\
\hline \multirow[t]{5}{*}{ Economic } & Economic profitability & $\begin{array}{l}\text { Peters and Waterman (1982); Schmalensee (1985); } \\
\text { Covin and Slevin (1990); McGahan (1990); Rumelt } \\
\text { (1991); García and Álvarez (1996); Camisón (1997); } \\
\text { Pelham (1997); Galán and Vecino (1997); McGa- } \\
\text { han and Porter (1997); Gadenne (1998); Mauri and } \\
\text { Michaels (1998); Camisón (1999); Pelham (2000); } \\
\text { Camisón (2001); Donrrosoro et al. (2001); Van Praag } \\
\text { and Versloot (2008); Ireland et al. (2009); Alene (2020) }\end{array}$ \\
\hline & Turnover & Hamilton (2000) \\
\hline & Annual results & $\begin{array}{l}\text { Hernández et al. (2005); Vergiú and Bendezú (2007); } \\
\text { De Jaime (2010); Varona et al. (2014) }\end{array}$ \\
\hline & Annual productivity & $\begin{array}{l}\text { García and Álvarez (1996); Camisón (1997); Marbella } \\
\text { (1998); Camisón (2001); Almeida and Fernando (2008) }\end{array}$ \\
\hline & Investment/employment ratio & Soto (2008) \\
\hline Financial & Financial profitability (and external funding) & $\begin{array}{l}\text { Covin and Slevin (1990); García and Álvarez (1996); } \\
\text { Camisón (1997); Marbella (1998); Camisón (2001); } \\
\text { Morillo (2001) }\end{array}$ \\
\hline Contextual & $\begin{array}{l}\text { Economic profitability, financial profitability, } \\
\text { asset turnover and indebtedness }\end{array}$ & March (1999) \\
\hline \multirow[t]{8}{*}{ Other } & Indicators of activity & $\begin{array}{l}\text { Peteraf (1993); Camisón (1997); Camisón (2001); } \\
\text { Delmar and Shane (2004) }\end{array}$ \\
\hline & Indicators of internationalisation & Dorronsoro et al. (2001) \\
\hline & Degree of innovation & Marbella (1998) \\
\hline & Wealth or value creation indices & $\begin{array}{l}\text { Kay (1993); Westhead and Cowling (1995); Almus } \\
\text { (2002) }\end{array}$ \\
\hline & Tobin's Q ratio & Wernerfelt and Montgomery (1988); McGahan (1999) \\
\hline & Capacity for innovation & Peters and Waterman (1982); Shepherd et al. (2000) \\
\hline & Socio-economic contribution & $\begin{array}{l}\text { Camisón (2001); Paige and Littrel (2002); Araujo de la } \\
\text { Mata et al. (2008) }\end{array}$ \\
\hline & Competitive position of the company & $\begin{array}{l}\text { García and Álvarez (1996); Camisón (2001); Hult et al. } \\
\text { (2005); Aragón and Rubio (2005) }\end{array}$ \\
\hline
\end{tabular}

Source: own elaboration

When measuring competitiveness, the objective components of the success of an entrepreneur should be studied, that is, the consideration should be based on facts and not on the opinion of the entrepreneur. As well as the survival of the business (which has already been mentioned), competitiveness is usually measured through quantitative indicators: economic, financial, contextual and others (Amorós \& Poblete, 2013; Garzón, 2017). Table 1 shows those indicators most commonly used for this purpose.

\section{Expectations}

Generically, expectation is the reasonable possibility that something should occur. Therefore, the expectations of entrepreneurs can be analysed taking into account previous results of the variables that define success in their business segment (Orozco \& Arraut, 2018). However, the expectations of entrepreneurs vary significantly with respect to their investment intentions and desired profitability (March, 1999). Many authors indicate the importance of the principles of social cognitive theory when considering both expectations of success and the perception of success itself, not just as elements which propitiate the acceleration of internal learning systems, but also for the achievement of success (Shin \& Kim, 2019). This focus is supported by different 
Table 2 Some indicators to measure expectations

\begin{tabular}{|c|c|c|}
\hline Types & Indicators & Authors \\
\hline \multirow[t]{2}{*}{ Expectations in context } & $\begin{array}{l}\text { Mean values at the commencement } \\
\text { of their activity in companies in their } \\
\text { business segment (such as: economic } \\
\text { profitability, financial profitability, asset } \\
\text { turnover, indebtedness, summary of } \\
\text { contextual expectations, etc.) }\end{array}$ & Padilla-Martínez et al. (2017) \\
\hline & $\begin{array}{l}\text { Business prospects and employment for } \\
\text { the following year }\end{array}$ & Padilla-Martínez et al. (2017) \\
\hline Aims & $\begin{array}{l}\text { Achievement of the entrepreneur's } \\
\text { objectives }\end{array}$ & $\begin{array}{l}\text { Ucbasaran et al. (2001); Ramos et al. (2010); } \\
\text { Ballester and Fernández (2016); Sánchez } \\
\text { et al. (2016) }\end{array}$ \\
\hline \multirow[t]{5}{*}{ Satisfaction or valuation } & Of employees & Camisón (2001) \\
\hline & Of clients & Covin and Slevin (1990); Luk (1996) \\
\hline & Of the company owner with the results & $\begin{array}{l}\text { Luk (1996); González (2003); Maehr and } \\
\text { Sjogren (1971); Khan et al. (2021) }\end{array}$ \\
\hline & $\begin{array}{l}\text { Of the company owner with growth in } \\
\text { sales }\end{array}$ & Luk (1996); González (2003) \\
\hline & $\begin{array}{l}\text { Of the company owner with the growth } \\
\text { of the workforce }\end{array}$ & $\begin{array}{l}\text { Camisón (1997); Camisón (2001); González } \\
\text { (2003) }\end{array}$ \\
\hline
\end{tabular}

Source: own elaboration

authors, with this initial variable being that which helps to define the future project. For this reason, the decision whether or not to invest in a business can be predicted on the basis of its expectation of survival and future returns, due partly to the perception of the risk assumed by the entrepreneurs (Su \& Wang, 2018). Logically, the role of public support will be different, depending on this perception and on the strategy taken by the entrepreneur as a follower or pioneer in the market (Shepherd, 1999).

To correctly understand the expectations and variables that should be taken into account so as to evaluate them, it is useful also to study the motivation of the entrepreneurs. The most frequent motivation is achievement, which coincides with the tendency to seek success in tasks which involve the evaluation of performance. The second motivation is power, which characterises the relationship between two persons in which one exercises control over the behaviour of the other. The third motivation is affiliation, which is defined as interest in establishing, maintaining or restoring a positive affective relationship with one or more persons (Montañés, 2002). It is clear that the expectations of entrepreneurs are particularly complex to evaluate, due to their subjectivity. They are usually measured in terms of the indicators included in Table 2.

\section{Evolution}

To complement the two above focuses, the trends and perspectives of the environment and the sector of the entrepreneur's activity must be considered. This evolution of the corresponding variables is considered both from the point of view of economic indicators (economic and financial profitability, growth in turnover and employees), and of contextual indicators (such as the average probability of survival of companies in the segment, business dynamism and its concentration). Consequently, the indicators in Table 3 should be taken into account. 
Table 3 Some indicators to measure evolution

\begin{tabular}{|c|c|c|}
\hline Types & Indicators & Authors \\
\hline \multirow[t]{6}{*}{ Economic } & Growth in investment & $\begin{array}{l}\text { Cuesta (2004); Aragón and Rubio (2005); Hayter } \\
\text { (2015) }\end{array}$ \\
\hline & Growth in employee numbers & $\begin{array}{l}\text { Cooper et al. (1989); Acar (1993); Westhead and } \\
\text { Cowling (1995); Dorronsoro et al. (2001); Almus } \\
\text { (2002); Van Praag and Versloot (2008) }\end{array}$ \\
\hline & Growth in sales & $\begin{array}{l}\text { Clifford and Cavanagh (1985); Covin and Slevin } \\
\text { (1990); Acar (1993); Wijewardena and Cooray } \\
\text { (1995); García and Álvarez (1996); Camisón (1997); } \\
\text { Pelham (2000); Camisón (2001); Dorronsoro et al. } \\
\text { (2001) }\end{array}$ \\
\hline & Growth in profits & $\begin{array}{l}\text { Clifford and Cavanagh (1985); Kalleberg and } \\
\text { Leicht (1991); Paige and Littrel (2002) }\end{array}$ \\
\hline & Growth in specific items on the balance sheet & Peters \& Waterman, 1982; Ronstadt, 1989 \\
\hline & Growth in market share & Chang and Singh (2000) \\
\hline \multirow[t]{3}{*}{ Contextual } & Evolution of the business segment & $\begin{array}{l}\text { March (1999); Weller (2006); Padilla-Meléndez } \\
\text { et al. (2007); De Castro (2012); Orozco and Arraut } \\
\text { (2018) }\end{array}$ \\
\hline & Indicator of expectations in the sector & $\begin{array}{l}\text { March (1999); Weller (2006); Padilla-Meléndez } \\
\text { et al. (2007); De Castro (2012); Orozco and Arraut } \\
\text { (2018) }\end{array}$ \\
\hline & $\begin{array}{l}\text { Evolution of economic indicators in the envi- } \\
\text { ronment }\end{array}$ & Azócar et al. (2003); Covarrubias (2003) \\
\hline
\end{tabular}

Source: own elaboration

Note that the evolution of the business segment is usually measured through the average growth in economic profitability and financial profitability from the beginning of activity by companies in the same business segment, while the evolution of economic indicators in the environment refers to the probability of survival in the environment, the dynamism of the business segment, the concentration of the business segment, a summary indicator of the environment, etc.

\section{Research methodology}

The three focuses described above are fundamental to determine a set of variables related to business success which help to classify entrepreneurs into three key groups or categories (separate groups, as defined in the Introduction): success, survival and failure.

To date, attempts to decide whether success has been achieved in a specific case of entrepreneurship on the basis of a single indicator have failed. Does this mean that success cannot be defined quantitatively? The solution offered to this problem consists of a somewhat more complex procedure than the calculation of an indicator, as it incorporates qualitative variables and takes into account a certain degree of subjectivity.

In this paper we only use variables which are related to success, not those which justify it. That is, we try to identify which questions are the best to find out whether an entrepreneur has been successful or not. Using a decision-tree technique, the optimal questions are recursively selected to divide the data set according to the previously chosen characteristics, so that each data subset has the best classification process. Once the questions with which to define success (or survival or failure) have been determined, this definition could be used to design prediction models (from a priori variables). 


\section{Data set}

To illustrate and check the model proposed to evaluate success, a data set was used relating to Andalusia, a region in the south of Spain with high levels of unemployment and where support for entrepreneurship is on the agenda of all of the politicians aiming to palliate the difficult situation, especially in the case of youth unemployment.

Specifically, information was obtained on 5341 entrepreneurs who had received advice or support since 2010 from the 'Andalucía-Emprende' support service. The support service collected information from all the entrepreneurs, since their consent for the processing of personal data for research is a condition of participation in the support program. In fact, entrepreneurs are willing to collaborate with Andalucía-Emprende motivated by the annual prizes awarded to the best entrepreneurs in the region. Hence, multiple variables are known for each of these entrepreneurs, relating to data on the company creation process and the monitoring that was carried out. In order for the information to incorporate aspects of positioning, expectations and evolution, of both the entrepreneurs and the context in their sectors, it was decided to complement the variables from the company database (the Iberian Balance System, 'Sistema de Balances Ibéricos', a database of financial information on the balance sheets of Spanish companies) with those of a geographical database (the Andalusian Municipal Information System, 'Sistema de Información Municipal Andaluz'). There exists another element which justifies resort to other sources to evaluate SMEs and micro-SMEs: it is recommended the use of the subjective variables regarding performance and environment (Covin \& Slevin, 1991); they better reflect those intangible factors that affect the early years of activity.

After analysing the large database and eliminating inconsistent information, the set of variables (described in the following section) and their corresponding useful levels to guarantee success (and survival or failure) were decided. Finally, all of the variables were integrated into a series of questions, and the final set of entrepreneurs consisted of 2221 individual cases. An in-depth analysis of this data set and the variables included can be found in Chaves et al. (2018).

\section{Variables}

Due to the great complexity and large number of tangible and intangible factors affecting success, depicted by both qualitative and quantitative variables, it was decided to use a multidimensional definition based on the three focuses defined above (expectations, positioning and evolution). Overall, these focuses serve to classify the variables into three groups which will be indicated by the first of two numbers in square brackets. These digits are used to design the variables finally included in the study.

From the articles referred to above (Peters \& Waterman, 1982; Schmalensee, 1985; Covin \& Slevin, 1990; McGahan, 1990; Audretsch, 1991; Rumelt, 1991; García \& Álvarez, 1996; Camisón, 1997, 1999, 2001; Pelham, 1997, 2000; Galán \& Vecino, 1997; McGahan \& Porter, 1997; Gadenne, 1998; Mauri \& Michaels, 1998; Donrrosoro et al., 2001; Van Praag \& Versloot, 2008; Ireland et al., 2009), it can be deduced that survival and economic profitability are the indicators most frequently used to measure success. They are, therefore, included here as fundamental elements. Other less commonly used indicators were considered to measure the situation of the sector and the geographical 
environment, where the activity took place. Finally, with the available information, summary indicators were constructed in order, for example, to ascertain whether the economic figures of the entrepreneur were favourable with respect to the mean value for companies in the business sector (the median value, for instance, is not available in the databases which have been accessed). The variables used are described in Appendix.

\section{Procedure}

The proposed model attempts to identify the ideal questions to classify entrepreneurs. These questions are compatible with the existing literature and with the variables listed in Appendix. Andalucía-Emprende carries out a follow-up survey to all the entrepreneurs 2 years after the beginning of their activity. Hence, the answers to almost all the questions in our set come from this survey and refer to the end of the second year of each project. This being the case, we set that moment as the most appropriate to evaluate whether they have been successful or not. However, we are about to see that questions $Q_{1}$ and $Q_{3}$ refer specifically to survival during the first years, with special attention to what happens at the end of the first year, as will be explained later.

The process to determine the following minimal set of questions from the variables labelled above is based on the C4.5 algorithm developed by Quinlan (1993), which in turn is an extension of the ID3 algorithm: at each step, one chooses the question that minimizes the diversity (or entropy) of the resulting subsets (considering the three classes "success", "survival", and "failure"). The algorithm usually guarantees only a local minimum of the number of nodes. Globality is achieved through the heuristic pruning process through backtracking which, in this case, was carried out by hand. It was possible to carry out the calculations by hand thanks to the fact that the questions are "discrete" and this fact simplifies their execution, but it would be much more complex in the case of "continuous" questions. The procedure is straightforward but too long to be described here. ${ }^{1}$ The risk of suffering the effects of overtraining is small, since entrepreneurs of almost all possible combinations of characteristics were classified (there are some impossible combinations). The final set of questions is listed below.

$\mathrm{Q}_{1}$ : Was the entrepreneur surviving more than 1 year? $\mathrm{Q}_{2}$ : Was the entrepreneur surviving after 2 years? $\mathrm{Q}_{3}$ : Did the entrepreneur survive the whole first year? $\mathrm{Q}_{4}$ : Were the objectives for which the entrepreneur created the company achieved? $\mathrm{Q}_{5}$ : Is the turnover positive? $\mathrm{Q}_{6}$ : Are the results positive? $\mathrm{Q}_{7}$ : Are there zero operating results? $\mathrm{Q}_{8}$ : Is external funding greater than 75 per cent? $\mathrm{Q}_{9}$ : Is the economic profitability greater than the mean economic profitability of companies in the business segment with the same CNAE? $\mathrm{Q}_{10}$ : Is the economic profitability greater than 10 per cent? $\mathrm{Q}_{11}$ : Is the financial profitability greater than the mean for companies in the same business sector with the same CNAE? $\mathrm{Q}_{12}$ : Is the financial profitability greater than 10 per cent? $\mathrm{Q}_{13}$ : Does the entrepreneur have positive expectations of the future of the project? $\mathrm{Q}_{14}$ : Is labour productivity greater than the minimum annual wage? $\mathrm{Q}_{15}$ : Are the satisfaction indicators positive? $\mathrm{Q}_{16}:$ Has the entrepreneur hired more employees since the commencement of activity? $\mathrm{Q}_{17}$ : Is there a positive evolution? $\mathrm{Q}_{18}$ : Are there positive indicators in the local

\footnotetext{
${ }^{1}$ A detailed description of this process can be requested from the authors.
} 
environment, where the activity takes place? $\mathrm{Q}_{19}$ : Are there positive expectations in the business context in which the activity takes place? $\mathrm{Q}_{20}$ : Has the business segment of the entrepreneur grown since the activity commenced? $\mathrm{Q}_{21}:$ Has there been a positive evolution since commencement and are current expectations positive? $\mathrm{Q}_{22}$ : Has the environment seen positive expectations and growth since the commencement of the activity? $\mathrm{Q}_{23}$ : Has the entrepreneur significantly increased investment since commencement of the activity? $\mathrm{Q}_{24}$ : Is relative indebtedness greater than the mean value for companies in the same business sector? $\mathrm{Q}_{25}$ : Is asset turnover greater than the mean value for companies in the same business sector? $\mathrm{Q}_{26}$ : Is investment per employee greater than the annual minimum wage? $\mathrm{Q}_{27}$ : Are there positive perspectives for the business of the entrepreneur and the possibility of increasing the number of employees in the following year? $\mathrm{Q}_{28}$ : Is the monthly turnover per employee greater than the monthly minimum wage? $\mathrm{Q}_{29}$ : Are the evolution indicators positive?

\section{Results and discussion}

The application of the method to the sample of 2221 Andalusian entrepreneurs revealed the 218 different cases shown in Table 4. These cases constitute the possible scenarios obtained when applying decision-tree techniques to the data set.

Decision trees constitute a flexible and versatile methodology in different areas of knowledge. One could refer to different types of decision trees, depending on the purposes for which they are used: (i) to classify a data set; (ii) to ease some regression models; (iii) to solve optimization problems; (iv) to display an algorithm; (v) to choose the best strategy, as in Game Theory; etc. For instance, Chaves et al. (2018) use a decision tree to find out what factors (or a priori characteristics) would best serve to predict entrepreneurial survival; they could not predict success, because they did not have an appropriate definition of such concept.

The common feature of all decision trees is that the underlying topological graph has no cycles. On the contrary, there are crucial questions in some trees (such as the search for optimal paths, the determination of errors or the cross-validation) that have no interest in others. In our case, decision trees solve the problem of finding a reduced set of questions (or nodes) to classify a complex set of data. To do this, we use a variant of the C4.5 algorithm (Quinlan, 1993). Without decision trees, it would have been practically impossible to optimally organize the most efficient variables to classify individuals. Note that the starting point was a set of hundreds of variables that characterized several thousand individuals. The challenge was to obtain questions that were answered with the previously collected variables and that allowed to classify the individuals according to the level of success each entrepreneur presented. Once applied the decision-tree technique, the classification proposed for each case coincides with the perceptions of experts and support services. Later we will highlight the importance of this fact.

Regarding the ease of use of the definition, the maximum number of questions necessary to classify an entrepreneur was 12 , and the appropriate set of questions valid to classify each entrepreneur can be extracted from Table 4. In the case study, 130 cases of success were classified (5.85\% of the total), 1002 of survival (45.11\%), 1058 of failure $(47.64 \%)$ and 31 could not be classified as a result of a lack of sufficient information (1.40\%). The three most frequent combinations in the database were: 







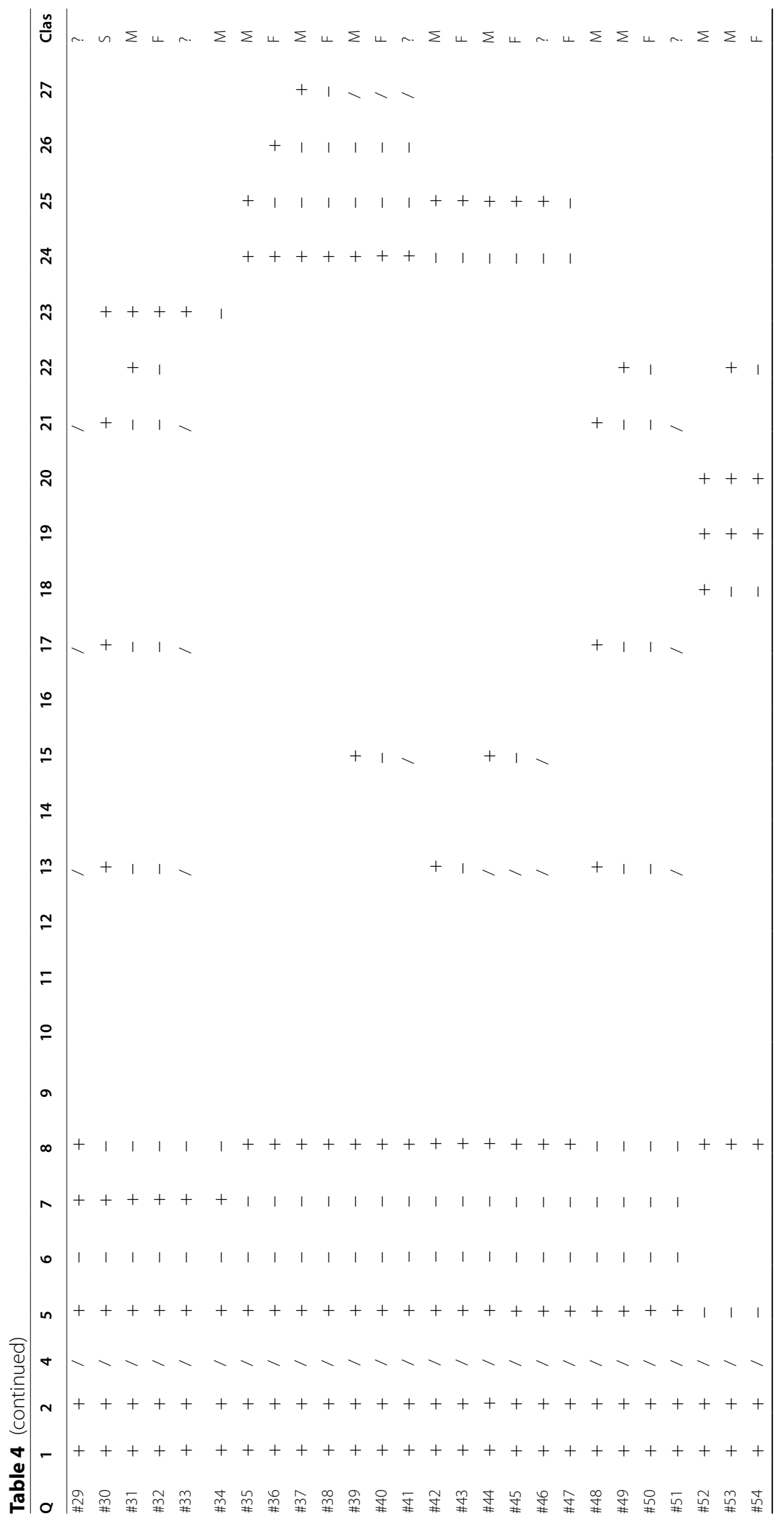




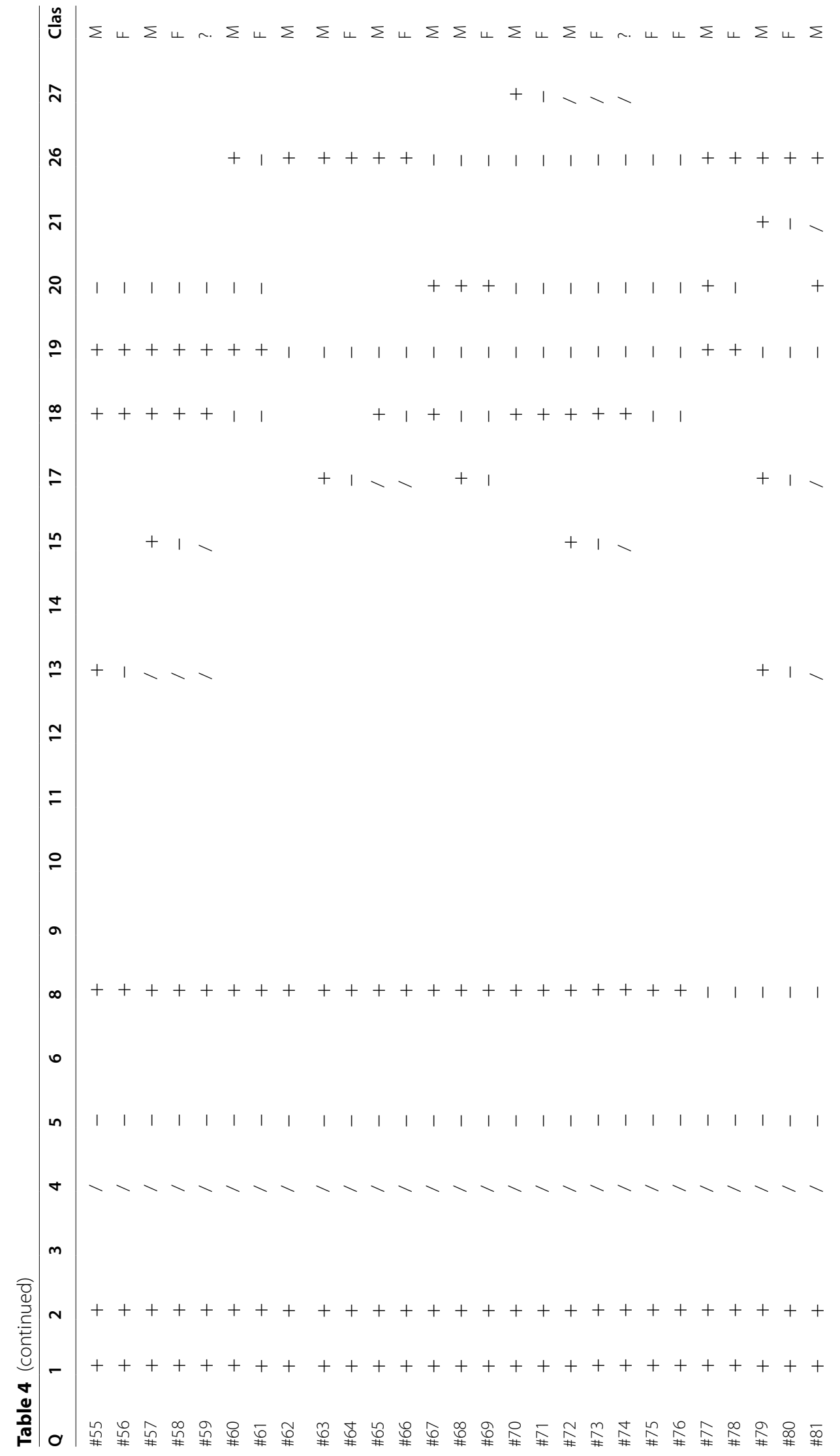




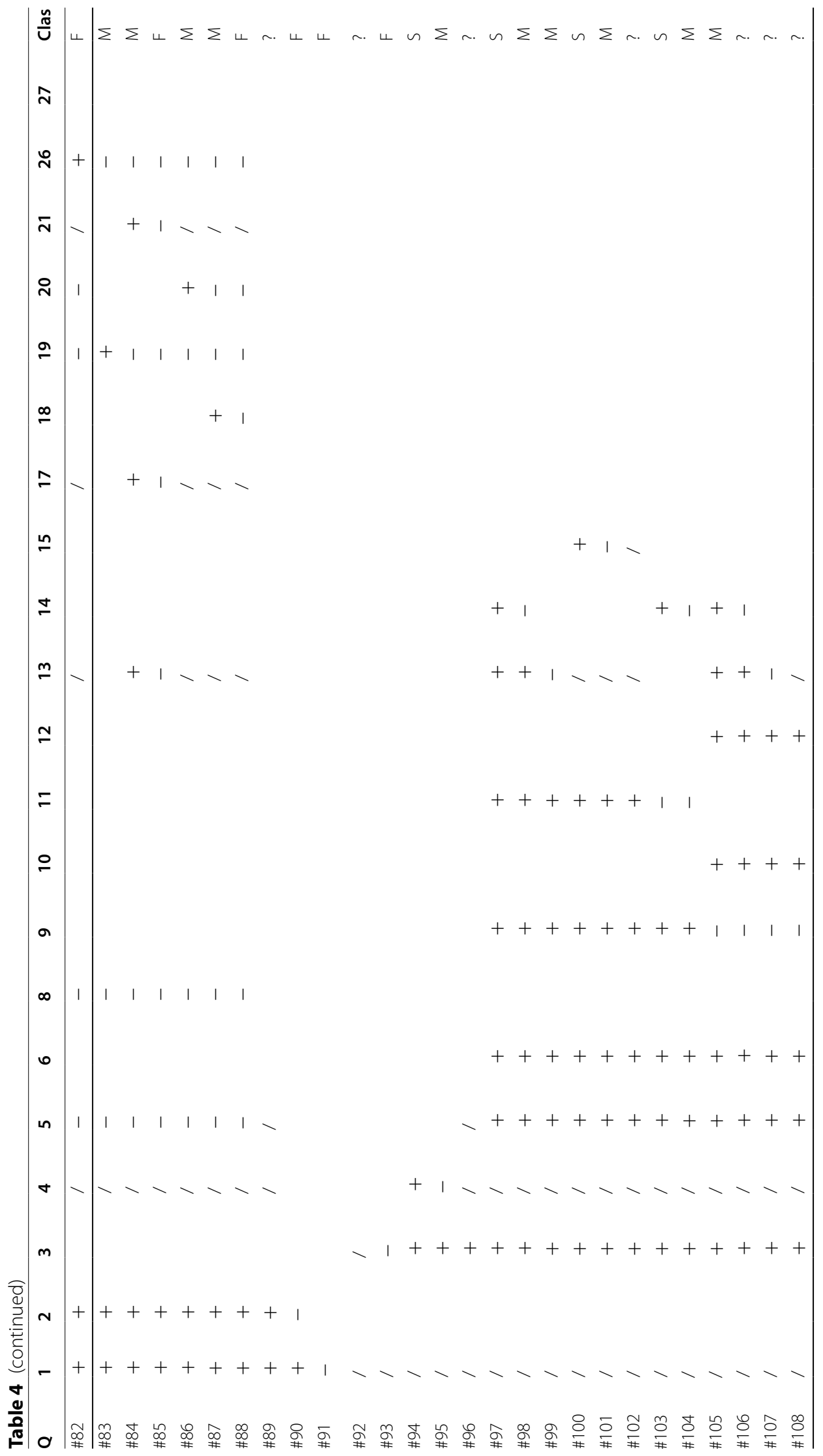




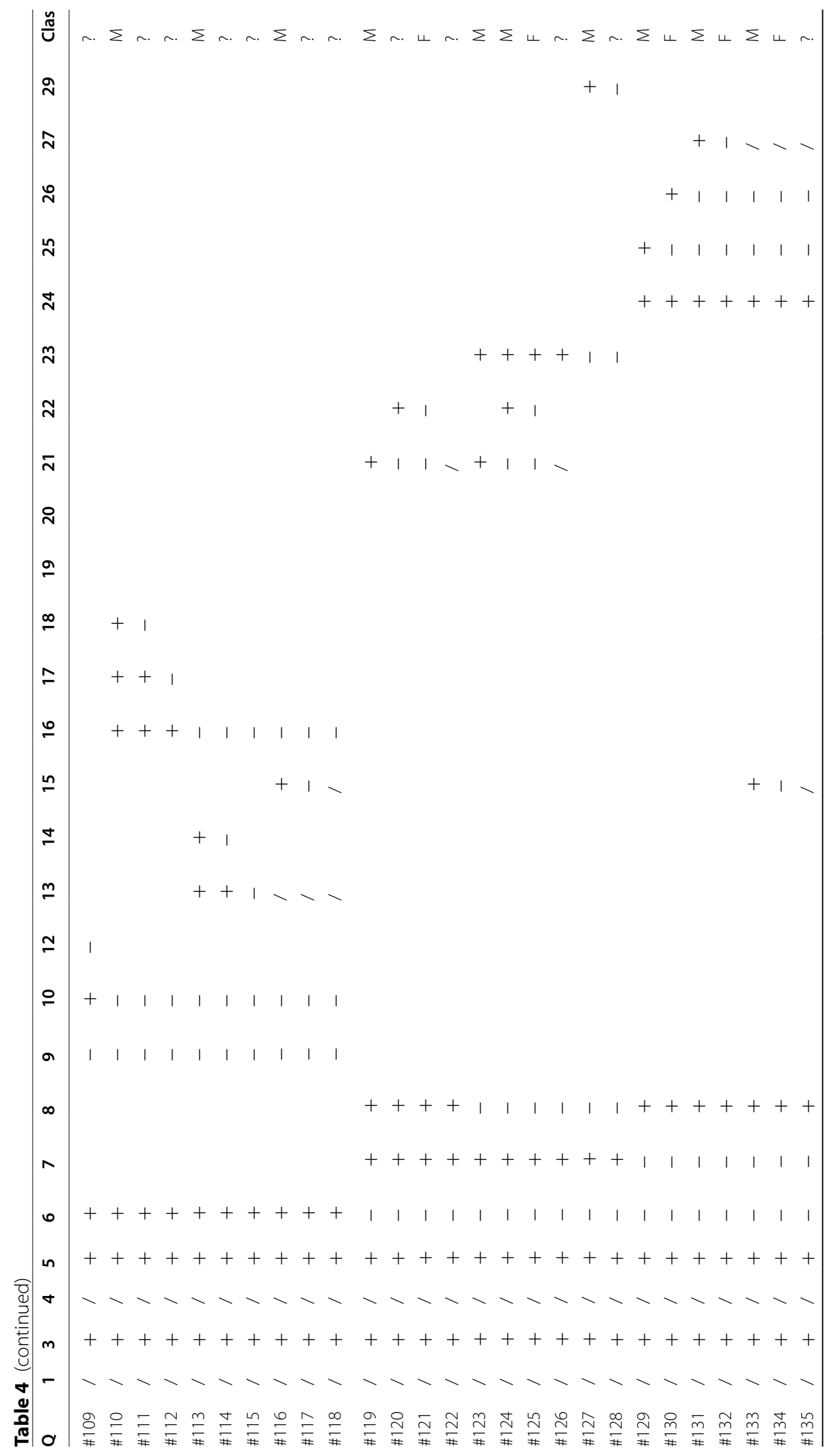




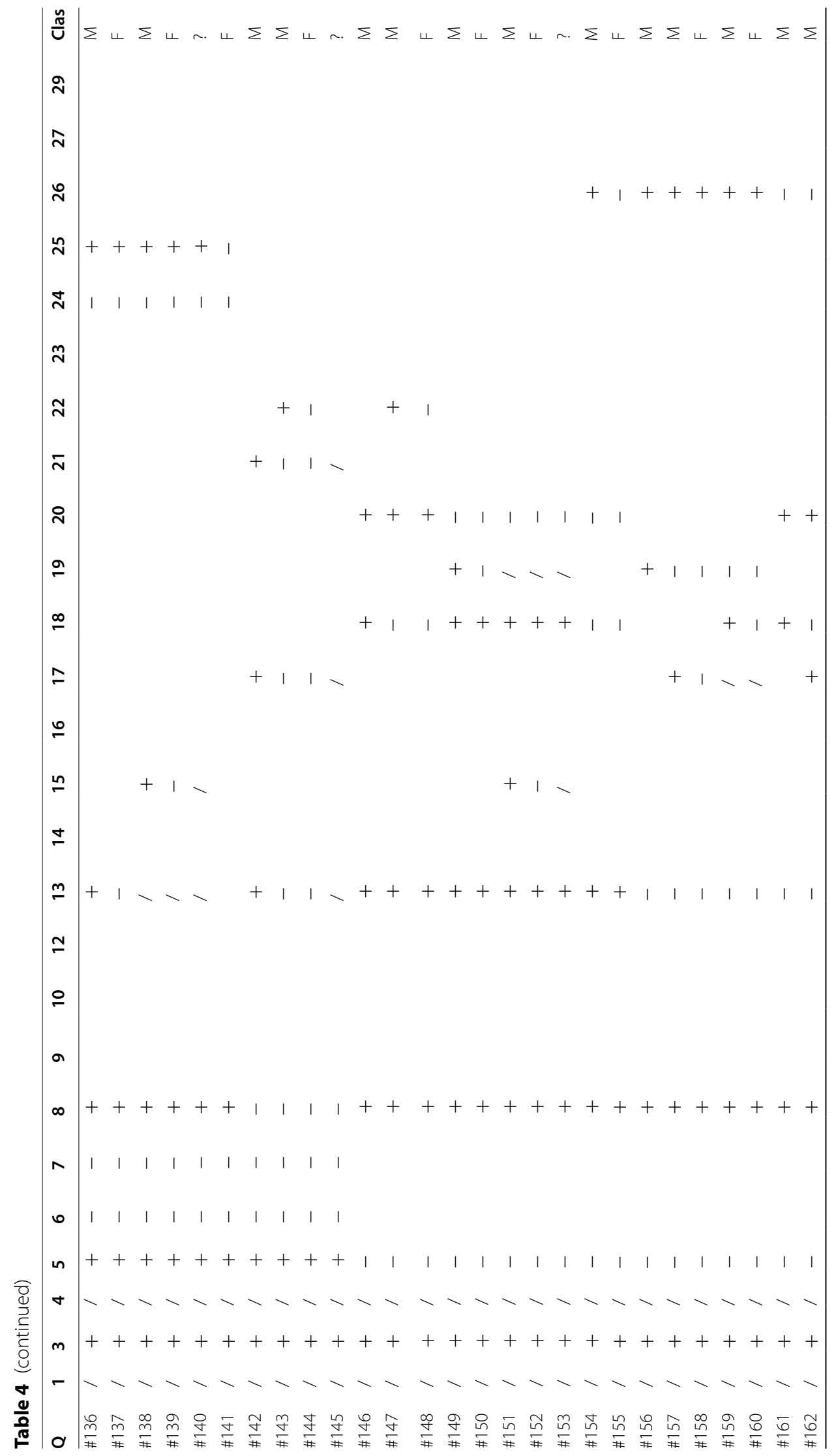




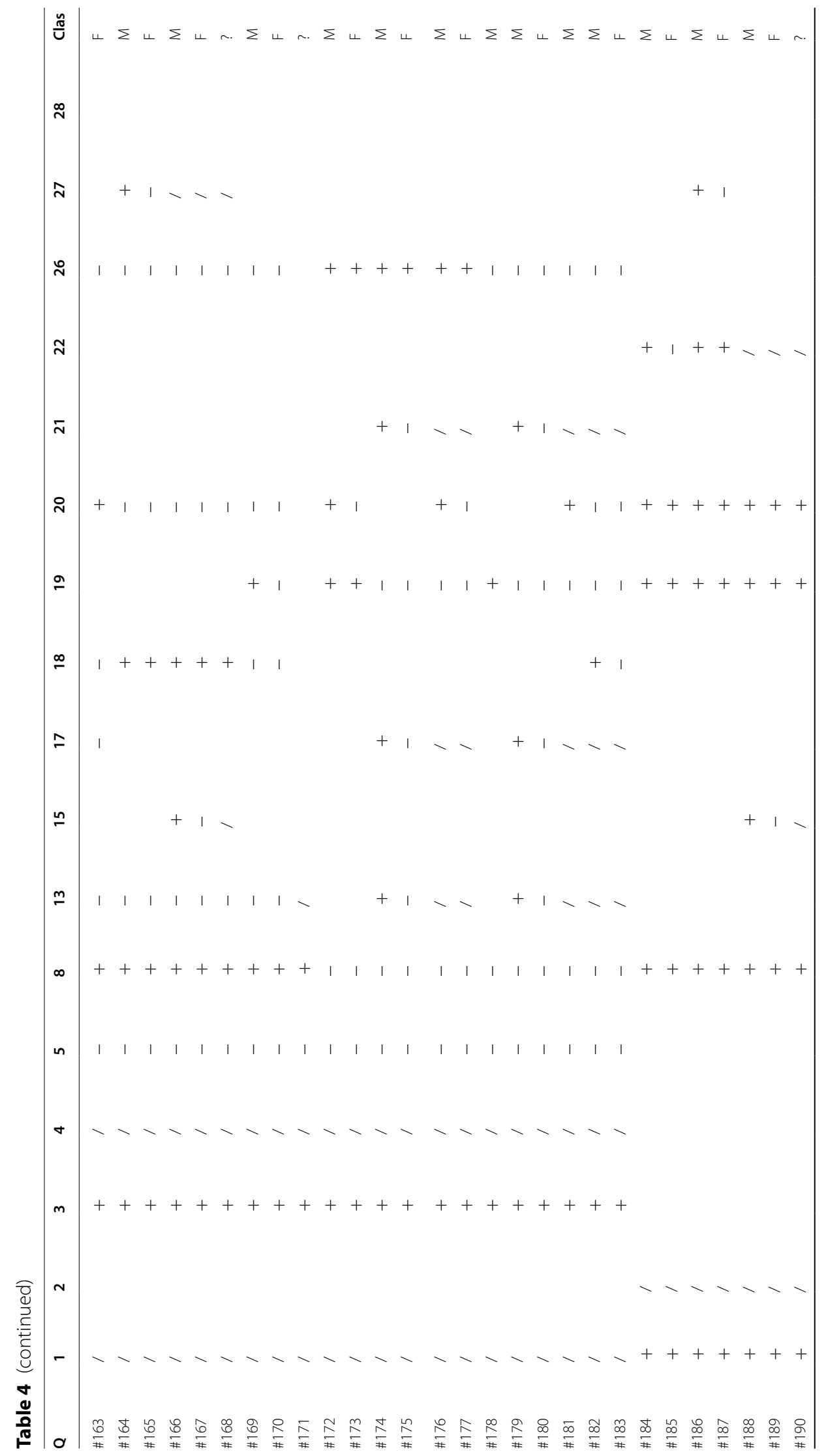




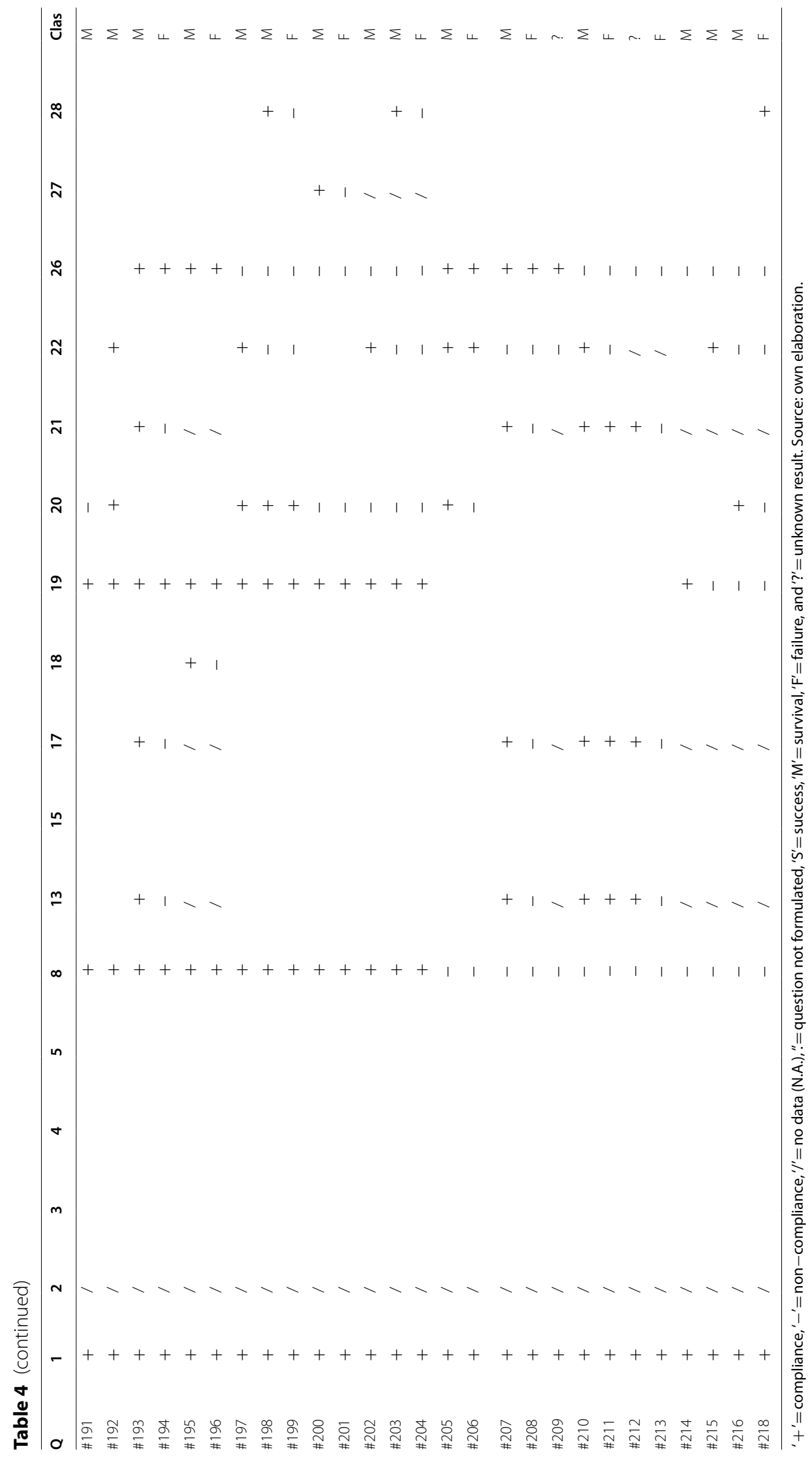


- \#90 (301 entrepreneurs, $14.12 \%$ of the database): $Q_{1}$ yes; $Q_{2}$ no; failure;

- \#11 (236 entrepreneurs, $11.07 \%$ of the database): $Q_{1}$ yes; $Q_{2}$ yes; $Q_{4}$ do not know/no answer; $Q_{5}$ yes; $Q_{6}$ yes; $Q_{9}$ no; $Q_{10}$ yes; $Q_{12}$ yes; $Q_{13}$ yes; $Q_{14}$ no; survival;

- \#9 (220 entrepreneurs, $10.32 \%$ of the database): $Q_{1}$ yes; $Q_{2}$ yes; $Q_{4}$ do not know/no answer; $Q_{5}$ yes; $Q_{6}$ yes; $Q_{9}$ yes; $Q_{11}$ no; survival.

The first (and most frequent) type of companies have failed, because they have not reached the 2-year border, unlike the second group that have had a positive performance, have achieved their objectives, and profitability has been higher than the rest of the companies in their business sector with the same CNAE. Finally, we highlight a third group that despite having exceeded 2 years, having positive performance and results, does not answer whether they achieved the objectives that were set and does not have a financial profitability above those of its own CNAE.

Reviewing cases such as these can help us reach an idea of whether the new definition makes sense. In fact, checking that the definition is reasonable or consistent would be a first step to validate it. As the tree outputs were all checked by experts, the credibility of the definition is high. Furthermore, the definition of success does not seem to depend on the characteristics that affect its achievement (such as characteristics of the entrepreneur or the project).

Second, we can ask whether the definition is generalizable. The answer is affirmative, but this does not mean that exactly the same table can be applied to evaluate success in another region, different from Andalusia. There are some aspects that should be adapted. For instance, it may affect the idiosyncrasy of the Spanish entrepreneur, who rarely considers that there can be something positive without survival. In any country, an important group of entrepreneurs consider survival as their principal objective of existence, hence it is a "moderate success" for them to maintain their activity. However, outside of Spain, it is more common to find entrepreneurs who value their learning as another step on their way to success (Soto-Simeone et al., 2021).

Another characteristic that may differ from another case study is the relevance of the first year after the start of the project. In Andalusia, the public support for entrepreneurs lasts exactly 1 year: the free assignment of a space, the training they receive, the web hosting, the participation in fairs and activities, etc. In other words, the first commitment of both parties (Andalucía-Emprende and each entrepreneur) lasts 1 year and it is quite common for the company to be extinguished at the end of that year. For this reason, a project that lasts more than 365 days differs from another that lasts exactly only 1 year.

Despite the above differences, the greatest difficulty in applying the definition in another region is probably the lack of a sufficiently complete and reliable data set. According to the interviews maintained by the authors and by the specialized publications reviewed, public entrepreneur support services have a lot of interesting data, but they rarely make use of it in a systematic way. Not using that information is probably one of their weakest points.

From now on, let us focus on the positive side: the flexibility in the use of the paper in other contexts. To do that, we will start with the variables used, which are common in any entrepreneur support service (or some equivalent variables). Quantitative and, above all, qualitative variables are used in the procedure, which facilitates 
its application. Besides, algorithm C4.5 was used instead of ID3, because it allows the presence of missing data (Quinlan, 1993).

The next aspect to consider is whether the definition is really useful. Entrepreneurship is not only essential to reduce unemployment, but also to improve the competitiveness of economy (Al Mamun \& Fazal, 2018; Spulber, 2014). After the latest economic crisis, growing agents of change like entrepreneurs are more amenable to new opportunities and challenges. We hold that our definition of success (and survival and failure) serves a dual purpose in improving entrepreneurship.

On one hand, it is necessary to define success to evaluate the situation of entrepreneurs and the support policies that they can benefit from. On the other hand, the establishment of an objective variable makes it possible to apply optimization, inference and simulation techniques with which to analyze the relevant factors to increase the success of entrepreneurs. Specifically, the results of this paper serve to improve those of other research works that sought to modernize support services for entrepreneurs.

Chaves et al. (2018) presented several factors that are important for survival in entrepreneurship: the total number of support services in the first months, passing a previous pre-incubation process, being present in an application for incentives or employment plan, as well as others such as the type of company or the geographic location. The forecast was acceptable for the entrepreneurs who survived; not so much for the others. Furthermore, only survival was analyzed and not success, because there was no appropriate definition of this last concept.

Chaves and Fedriani (2020) showed that a computer program can correctly guide an entrepreneur or, at least, help in this task to a support service for entrepreneurs. To do this, they developed a way to predict the success or survival of entrepreneurs based on the information available before starting the business venture. The system was based on Artificial Intelligence (specifically, a self-organizing map and a multilayer perceptron), and they consider objective variables compatible with the definitions explained in the present paper. The self-organizing map detected the following variables as the ones which affect the prediction highly: local productive environment; employment plan; type of business accommodation; financial profitability of the environment; supporting services; economic indicators of the environment; activity of the company; investment; financing; educational level; legal form; employees. According to the multilayer-perceptron, the more influential variables were: the sector; the probability of survival of the environment; the number of employees; the province; and the number of support services. Summarizing, a replicable entrepreneurial success prediction model was built, and it determined a different effect of certain actions in the counselling depending on the characteristics of the entrepreneur. However, artificial intelligence only works if provided with a proper definition of success; the same is true whatever inference technique you try to use for the same purpose.

Therefore, we hold that this paper will serve as the basis for the design of a scorecard that will make it possible to determine and monitor the evolution of the supported entrepreneurs, but also to improve the corresponding counselling process. For future research, we propose to analyse the relationship between survival and longterm success of the business project, since the definition of success in this paper uses information exclusively from the first 5 years of life of the entrepreneurial projects. 


\section{Conclusions}

Much has been written on the evaluation of business performance. This article has attempted to adapt the most commonly used indicators to the specific case of entrepreneurship, which has been studied much less (Choi \& Williams, 2016). The proposed definition of success is not the only one possible, but it is consistent, generalizable, and useful. Therefore, we can affirm that this paper provides a tool (based on the decision trees) which can serve to analyse the factors for success and, even, to estimate the probability of success. It would be reasonable, on the basis of the formulae for calculating this probability, to consider in the future a more precise definition of success for each entrepreneur, and this would facilitate the evaluation of measures to encourage entrepreneurship. This, in turn, would serve to improve systems to support entrepreneurs, an ultimate aim of undoubted economic and business interest.

The proposed definition of business success has been designed on the basis of all the variables introduced above (in Sect. 3.2), through a decision tree (or expert system), rooted in the bibliography consulted and expert recommendations, allowing a measurement of success to be established that is more precise than those proposed by other authors, especially for the type of entrepreneur studied in this research. In the case study, over 98 per cent of the entrepreneurs, (all those who were classifiable) were correctly classified with the combination of questions used, in accordance with the available information (from the public support service 'Andalucía-Emprende'). The method has been generalised so that it also allows the classification of other hypothetical cases (with combinations of values not found in the sample). It has not yet been checked whether the methodology can be adapted to evaluate other types of company or to study entrepreneurs when the available information is not so complete.

A significant proportion of the papers consulted to estimate business success are based on accounting information available from the registry, taking into account all of the legal considerations and recommendations for the calculation of indicators. This is due to the fact that companies are often reluctant to provide data (Covin \& Slevin, 1990; Pelham, 1997) and in many cases, the data is not entirely reliable. In the case study presented here, the data comes from an official, public source. Nevertheless, a possible response to each question is 'data not available', which demonstrates that the method can classify correctly despite abundant missing data.

In the event of replicating this study for another region, the greatest difficulty would be to obtain such a comprehensive and reliable database. Despite the little consideration given to business failure in Andalusia, most of the questions considered in this paper can be used to correctly classify entrepreneurs in any other country with a public service to support entrepreneurs.

The use of Artificial Intelligence is what makes it possible to consider so many variables. In turn, the use of such a complete database allows the achievement of reliable results, even when the information is incomplete or imprecise. This opens a range of possibilities for future research in the field of entrepreneurship and the evaluation of business success. 


\section{Appendix}

\section{Variables considered as indicators for entrepreneurial success}

- Survival of the business [1.1]: the action and effect of a company surviving, depending on whether or not it is registered, with regard to the legal and administrative procedures necessary, after a given period of time following its creation. In the case of entrepreneurs, this variable has a very strong inverse correlation with failure.

- Turnover [1.2]: the volume of the turnover produced by the exchange of goods and services by the company (measured in euros).

- Results [1.3]: this represents the amount of money that remains in the company when total expenditure on operations is deducted from total revenue from the company's operating activities (after interest and taxes).

- Relative economic profitability [1.4]: a comparison of net earnings and total assets, with respect to the mean value for companies in the business segment with the same National Economic Activity Code ('Código Nacional de Actividades Económicas', or CNAE).

- Relative financial profitability [1.5]: a comparison of net earnings (or profits or losses after interest and taxes) and stockholders' equity, with respect to the mean value for companies of the sector with the same CNAE.

- Productivity [1.6]: operating earnings divided by the number of employees.

- Investment/employment [1.7]: the volume of investment per employee.

- External funding [1.8]: the percentage of external funding with respect to total company capital.

- Competitive position of the company [1.9]: this is a multidimensional or vector indicator which compares the indicators of the company with the mean values for companies in its business sector with the same CNAE regarding: economic profitability, financial profitability, asset turnover and indebtedness.

- Contextual expectations [2.1]: the coefficient of the values of the entrepreneur and those of the context with respect to economic profitability, financial profitability and asset turnover.

- Business and employment perspectives for the following year [2.2]: subjective opinion of the entrepreneur regarding the prospects of the business and the capacity to hire more employees in the following year.

- Achievement of the objectives laid down [2.3]: this is the subjective assessment by the entrepreneur of the achievement of the objectives set at the beginning of the business activity.

- Satisfaction indicators [2.4]: this measures the satisfaction of the different stakeholders related to the company (employees, customers, owner of the company; for the latter, in terms of the results, growth in sales and growth of the workforce).

- Increase in investment [3.1]: a dichotomous variable that indicates whether the activity has required additional investment over and above the initial investment.

- Increase in the number of employees [3.2]: this variable indicates whether the company has more employees than at the commencement of its activity. 
- Evolution of the business segment [3.3]: the growth in the main indicators, economic and financial profitability, in the business segment with the same CNAE as the entrepreneur.

- Evolution of the growth in turnover and employees [3.4]: increase in the turnover and employee variables since the commencement of the activity up to the present. This is, in fact, a vector variable with two components, the first with three values ('increased,' 'unchanged' or 'reduced') and the second with four (the fourth being 'did not have workers under contract').

- Expectations of the sector [3.5]: a qualitative indicator that summarises the components of indicators 1.9; in the case that the components are all favourable, its value is 'positive'; otherwise, it is 'negative'.

- Evolution and expectations of the business segment: a qualitative indicator that summarises indicators 2.1 and 3.3; if the indicators are all favourable, its value is 'positive'; otherwise, it is 'negative'.

- Economic indicators of the environment [3.6]: representative values of the municipality, where the activity of the entrepreneur takes place, with respect to the probability of survival in that environment, the dynamism of the business segment and the concentration of the business segment.

Acknowledgements

We thank the anonymous Reviewer \#1 whose comments helped improve and clarify this manuscript.

\section{Authors' contributions}

EF mainly contributed to the study's conception and design. The preparation of the materials, data collection and analysis were performed by MC. The first draft of the manuscript was written by MC and corrected by EF. Both authors read and approved the final manuscript.

\section{Authors' informations}

M.C.-M. is PhD in Economy (2020, Pablo de Olavide University, Spain); Associate Professor at Pablo de Olavide University (Spain) in the Department of Economics, Quantitative Methods and Economic History. His research interests include entrepreneurial orientation and business assessment.

E.M.F. is PhD in Mathematics (2001, University of Seville, Spain); Full Professor at Pablo de Olavide University (Spain) in the Department of Economics, Quantitative Methods and Economic History. His research interests include Lie algebras, Graph Theory and the application of mathematical methods to Economics and Business.

\section{Funding}

This research was supported by Pablo de Olavide University (Spain) and data was collected from Andalucía Emprende Fundation that participates in the European Erasmus for Young Entrepreneurs project through the project called MOVE YE.

Availability of data and materials

The datasets generated and/or analysed during the current study are not publicly available due individual privacy, but are available from the corresponding author on reasonable request.

\section{Declarations}

\section{Competing interests}

The authors declare that they have no competing interests.

Received: 1 June 2021 Accepted: 27 November 2021

Published online: 22 February 2022

\section{References}

Acar, A. C. (1993). The impact of key internal factors on firm performance: An empirical study of small Turkish firms. Journal of Small Business Management, 31(4), 86-92.

Al Issa, H. (2021). Advancing entrepreneurial career success: the role of passion, persistence, and risk-taking propensity. Entrepreneurial Business and Economics Review. https://doi.org/10.15678/EBER.2021.090209 
Al Mamun, A., \& Fazal, S. A. (2018). Effect of entrepreneurial orientation on competency and micro-enterprise performance. Asia Pacific Journal of Innovation and Entrepreneurship, 12(3), 379-398. https://doi.org/10.1108/ APJIE-05-2018-0033

Alene, E. T. (2020). Determinants that influence the performance of women entrepreneurs in micro and small enterprises in Ethiopia. Journal of Innovation and Entrepreneurship, 9, 24. https://doi.org/10.1186/s13731-020-00132-6

Alkahtani, A., Nordin, N., \& Khan, R. U. (2020). Does government support enhance the relation between networking structure and sustainable competitive performance among SMEs? Journal of Innovation and Entrepreneurship. https:// doi.org/10.1186/s13731-020-00127-3

Almeida, S., \& Fernando, M. (2008). Survival strategies and characteristics of start-ups: An empirical study from the New Zealand IT industry. Technovation, 28, 161-169.

Almus, M. (2002). What characterizes a fast-growing firm? Applied Economics, 34, 1497-1508.

Amorós, J. E., \& Poblete, C. (2013). Global Entrepreneurship Monitor: Reporte de Actividad Emprendedora en Chile 2012. Ediciones Universidad del Desarrollo.

Aragón, A., \& Rubio, A. (2005). Factores explicativos del éxito competitivo: el caso de las pymes del estado de Veracruz. Contaduría y Administración. https://doi.org/10.22201/fca.24488410e.2005.568

Araujo de la Mata, A., Barrutia, J., \& Retolaza, J.L. (2008). "Nuevo enfoque en los modelos de creación de empresas. Estableciendo puentes en una economía global". Escuela Superior de Gestión Comercial y Marketing, ESIC, 1, p. 101. Retrieved from: https://es.scribd.com/document/299396779/Nuevos-modelos-creacion-empresas-pdf

Audretsch, D. (1991). New-firm survival and the technological regime. Review of Economics and Statistics, 73, 441-450.

Azócar, G., Sanhueza, R., \& Henríquez, C. (2003). Cambio en los patrones de crecimiento en una ciudad intermedia: El caso de Chillán en Chile Central. Eure (santiago), 29(87), 79-82.

Ballester, S. G. \& Fernández, M. I. R. (2016). Valores de éxito y emprendimiento. Revista Infad De Psicología, 1(2), 171-184

Bazan, C., Gaultois, H., Shaikh, A., Gillespie, K., Frederick, S., Amjad, A., Yap, S., Finn, C., Rayner, J., \& Belal, N. (2020). A systematic literature review of the influence of the university's environment and support system on the precursors of social entrepreneurial intention of students. Journal of Innovation and Entrepreneurship, 9, 4. https://doi.org/10. 1186/s13731-020-0116-9

Brown, H. S., De Jong, M., \& Lessidrenska, T. (2009). The rise of the global reporting initiative: A case of institutional entrepreneurship. Environmental Politics, 18(2), 182-200.

Camisón, C. (1999). "Sobre cómo medir las competencias distintivas: un examen empírico de la fiabilidad y validez de los modelos multi-item para la medición de los activos intangibles". In: First International Conference of The Iberoamerican Academy of Management: "Management Related Theory and Research: An Iberoamerican Perspective (pp. 9-11). Madrid: Universidad Carlos III.

Camisón, C. (1997). La competitividad de la pyme industrial española: Estrategia y competencia distintivas. Civitas.

Camisón, C. (2001). La investigación sobre la PYME y su competitividad. Balance del estado de la cuestión desde las perspectivas narrativa y meta-analítica. Papeles De Economía Española, 89-90, 43-86.

De Castro, S. (2012). Dimensiones de personalidad, motivación de logro y expectativas de control en jóvenes emprendedores brasileños. Ph. D. Thesis. Universidad de León.

Cefis, E., \& Marsili, O. (2011). Born to flip. Exit decisions of entrepreneurial firms in high-tech and low-tech industries. Journal of Evolutionary Economics, 21, 473-498.

Chadha, S., \& Dutta, N. (2020). Linking entrepreneurship, innovation and economic growth: Evidence from GEM countries. International Journal of Technoentrepreneurship, 4(1), 22-31.

Chang, S. J., \& Singh, H. (2000). Corporate and industry effects on business unit competitive position. Strategic Management Journal, 21(7), 739-752.

Chaves, M., \& Fedriani, E. M. (2020). Entrepreneurship support ways after the COVID-19 crisis. Entrepreneurship and Sustainability /ssues, 8(2), 662-681. https://doi.org/10.9770/jesi.2020.8.2(40)

Chaves, M., Fedriani, E. M., \& Ordaz, J. A. (2018). Factores relevantes para optimizar los servicios públicos de apoyo a los emprendedores y la tasa de supervivencia de las empresas. Innovar, 28(69), 9-24.

Choi, S. B., \& Williams, C. (2016). Entrepreneurial orientation and performance: Mediating effects of technology and marketing action across industry types. Industry and Innovation, 23(8), 673-693. https://doi.org/10.1080/13662716. 2016.1208552

Claire, L. (2012). Re-storying the entrepreneurial ideal: lifestyle entrepreneurs as hero? TAMARA, 10, 31-39.

Clifford, D. K., \& Cavanagh, R. E. (1985). The winning performance. Bantam Books.

Cooper, A. C., Woo, C. Y., \& Dunkelberg, W. C. (1989). Entrepreneurship and the initial size of firms. Journal of Business Venturing, 4, 317-332.

Covarrubias, I. (2003). "Emprendedores y Empresarios: un enfoque Institucional". Revista Contribuciones a la Economía. Retrieved from: http://www.eumed.net/ce/icm-emp.htm

Covin, J. G., \& Slevin, D. P. (1990). New venture strategic posture, structure, and performance: An industry life cycle analysis. Journal of Business Venturing, 5(2), 123-135.

Covin, J. G., \& Slevin, D. P. (1991). A conceptual model of entrepreneurship as firm behavior. Entrepreneurship Theory and Practice, 16(1), 7-26.

Cuesta, P. (2004). La franquicia: Una fórmula comercial con éxito en pleno crecimiento. Distribución y Consumo, 78, 5-13.

De Jaime, J. (2010). Las claves del análisis económico-financiero de la empresa. ESIC Editorial.

Delmar, F., \& Shane, S. (2004). Legitimating first: Organizing activities and the survival of new ventures. Journal of Business Venturing, 19(3), 385-410.

Donrrosoro, I., García, C., González, M., Lezámiz, M., Matey, J., Moso, M., \& Unzuela, M. (2001). El modelo de gestión de las PyMEs vascas de éxito. Clúster del Conocimiento y Ediciones PMP.

Duchesneau, D. A., \& Gartner, W. B. (1990). A profile of new venture success and failure in an emerging industry. Journal of Business Venturing, $5,297-312$

Gadenne, D. (1998). Critical success factors for small business: An inter-industry comparison. International Small Business Journal, 7(1), 36-56. 
Galán, J. L., \& Vecino, J. (1997). Las fuentes de rentabilidad de las empresas. Revista Europea De Dirección y Economía De La Empresa, 6(1), 21-36.

García, E., \& Álvarez, J. C. (1996). Factores de éxito y riesgo en la pyme: Diseño e implantación de un modelo para la mejora de la competitividad. Economía Industrial, 310, 149-161.

Garzón, D.M. (2017). Desarrollo de indicadores de gestión, como medio para el aumento de la productividad en una pyme del sector de desarrollo tecnológico. Bachelor's Thesis, Universidad Militar Nueva Granada.

Gómez-Gómez, J., Martínez-Costa, M., \& Martínez-Lorente, Á. R. (2016). Weighting the dimensions in models of excellence -a critical review from a business perspective. Measuring Business Excellence, 20(3), 79-90.

Gómez-Villanueva, J. E. (2008). Orientación al mercado, capacidades empresariales y resultados en las PYMES de nueva creación. Universitat Autònoma de Barcelona, Departament d'Economia de l'Empresa.

González, A.M.O. (2003). Fomento de la iniciativa emprendedora en el estudiante universitario: la autoeficacia percibida emprendedora. Ph. D. Thesis, Universidad de Sevilla.

Hamilton, B. H. (2000). Does entrepreneurship pay? An empirical analysis of the returns to self-employment. Journal of Political Economy, 108(3), 604-631.

Harms, R., Kraus, S., \& Reschke, C. H. (2007). Configurations of new ventures in entrepreneurship research: Contributions and research gaps. Management Research News, 30, 661-673.

Hayter, C. S. (2015). Social networks and the success of university spin-offs toward an agenda for regional growth. Economic Development Quarterly. https://doi.org/10.1177/0891242414566451

Headd, B. (2003). Redefining business success: Distinguishing between closure and failure. Small Business Economics, 21 , $51-61$.

Hernández, L., Meneses, L. Á., \& Benavides, J. (2005). Desarrollo de una metodología propia de análisis de crédito empresarial en una entidad financiera. Estudios Gerenciales, 21(97), 129-165.

Hovig, O., Pettersen, I. B., \& Aarstad, J. (2018). Entrepreneurial causation vs. effectuation in a business incubation context: Implications for recruiting policy and management. Entrepreneurship Research Journal. https://doi.org/10.1515/ erj-2017-0065

Hult, G. T. M., Ketchen, D. J., \& Slater, S. F. (2005). Market orientation and performance: An integration of disparate approaches. Strategic Management Journal, 26, 1173-1181.

Ireland, R. D., Covin, J. G., \& Kuratko, D. F. (2009). Conceptualizing corporate entrepreneurship strategy. Entrepreneurship Theory and Practice, 33, 19-46.

Kalleberg, A. L., \& Leicht, K. T. (1991). Gender and organizational performance: Determinants of small business survival and success. Academy of Management Journal, 34(1), 136-161.

Kay, J. (1993). Foundations of corporate success: How business strategies add value. Oxford University Press.

Kester, W. C., \& Luehrman, T. A. (1989). Are we feeling more competitive yet? The exchange rate gambit. The International Executive, 31(3), 40-43.

Khalilov, L., \& Yi, Ch. D. (2021). Institutions and entrepreneurship: Empirical evidence for OECD countries. Entrepreneurial Business and Economics Review. https://doi.org/10.15678/EBER.2021.090208

Khan, R. U., Salamzadeh, Y., Shah, S. Z. A., \& Hussain, M. (2021). Factors affecting women entrepreneurs' success: A study of small- and medium-sized enterprises in emerging market of Pakistan. Journal of Innovation and Entrepreneurship, 10, 11. https://doi.org/10.1186/s13731-021-00145-9

Kiyabo, K., \& Isaga, N. (2020). Entrepreneurial orientation, competitive advantage, and SMEs' performance: Application of firm growth and personal wealth measures. Journal of Innovation and Entrepreneurship, 9, 12. https://doi.org/10. 1186/s13731-020-00123-7

Luk, T. K. (1996). Success in Hong Kong: Factors self-reported by successful small business owners. Journal of Small Business Management, 34(3), 68-74.

Maehr, M. L., \& Sjogren, D. D. (1971). Atkinson's theory of achievement motivation: First step toward a theory of academic motivation? Review of Educational Research, 41 (2), 143-161.

Marbella, F. (1998). "Competitividad de las empresas castellano-leonesas: Análisis de algunos factores relevantes". In: VI Congreso de Economía Regional de Castillay León, Zamora. Retrieved from: http://www.jcyl.es/jcyl/cee/dgeae/ congresos_ecoreg/CERCL/831.PDF

March, I. (1999). Las claves del éxito en nuevas compañías innovadoras. Dirección y Organización, 21, 177-186.

Mauri, A. J., \& Michaels, M. P. (1998). Firm and industry effects within strategic management: An empirical examination. Strategic Management Journal, 19(3), 211-219.

McGahan, A. M. (1990). The effect of incomplete information about demand on entry deterrence. Division of Research, Harvard Business School.

McGahan, A. M. (1999). The performance of US corporations: 1981-1994. The Journal of Industrial Economics, 47(4), 373-398.

McGahan, A. M., \& Porter, M. E. (1997). How much does industry matter, really? Strategic Management Journal, 18, 15-30.

Montañés, M. C. (2002). El proceso motivacional. Universidad de Valencia.

Morillo, M. (2001). Rentabilidad financiera y reducción de costos. Actualidad Contable Faces, 4(4), 35-48.

Morris, M., Schindehutte, M., \& Allen, J. (2005). The entrepreneur's business model: Toward a unified perspective. Journal of Business Research, 58(6), 726-735.

Nikolic, N., Jovanovic, I., Nikolic, D., Mihajlovic, I., \& Schulte, P. (2019). Investigation of the factors influencing SME failure as a function of its prevention and fast recovery after failure. Entrepreneurship Research Journal, 9(3), 1-21. https://doi. org/10.1515/erj-2017-0030

Orozco, J., \& Arraut, L. C. (2018). Los emprendedores con altas expectativas de crecimiento y el crecimiento económico. Dimensión Empresarial, 16(8), 85-98. https://doi.org/10.15665/rde.v16i2.828

Padilla-Martínez, M. P., Quispe-Otacoma, A. L., Nogueira-Rivera, D., \& Hernández-Nariño, A. (2017). Diagnóstico y perspectivas de fomento del emprendimiento como instrumento de desarrollo/The entrepreneurship as business management for sustainable development. Ingeniería Industrial, 38(2), 199-205.

Padilla-Meléndez, A., Garrido-Moreno, \& A. (2007). Estrategias CRM en empresas hoteleras. estado de la investigación y definición de un modelo de éxito integrador. Revista De Análisis Turístico, 3, 45-60. 
Paige, R. C., \& Littrell, M. A. (2002). Craft retailers' criteria for success and associated business strategies. Journal of Small Business Management, 40(4), 314-331.

Pelham, A. M. (1997). Mediating influences on the relations between market orientation and profitability in small industrial firms. Journal of Marketing Theory and Practice, 5(3), 55-76.

Pelham, A. M. (2000). Market orientation and other potential influences on performance in small and medium-sized manufacturing firms. Journal of Small Business Management, 38(1), 48-67.

Peteraf, M. A. (1993). The cornerstones of competitive advantage: A resource-based view. Strategic Management Journal, $14,179-191$.

Peters, T. J., \& Waterman, R. H. (1982). In search of excellence: Lessons from America's best-run companies. Collins Business Essentials.

Porter, M. E. (1991). La ventaja competitiva de las naciones. Vergara.

Quinlan, J. R. (1993). C4.5: Programs for machine learning. Morgan Kaufmann Publishers.

Ramos, C. G., Campillo, A. M., \& Gago, R. F. (2010). Características del emprendedor influyentes en el proceso de creación empresarial y en el éxito esperado. Revista Europea De Dirección y Economía De La Empresa, 19(2), 31-47.

Ronstadt, R. (1989). The corridor principle. Journal of Business Venturing, 3, 31-40.

Rumelt, R. P. (1991). How much does industry matter? Strategic Management Journal, 12(3), 167-185.

Sánchez, J. M., Vélez, M. L., \& Araújo, P. (2016). Balanced scorecard para emprendedores: desde el modelo. Revista Facultad De Ciencias Económicas: Investigación y Reflexión, 24(1), 37-47. https://doi.org/10.18359/rfce.1620

Schmalensee, R. (1985). Do markets differ much? The American Economic Review, 75(3), 341-351.

Shepherd, D. A. (1999). Venture capitalists' assessment of new venture survival. Management Science, 45, 621-632.

Shepherd, D. A., Douglas, E. J., \& Shanley, M. (2000). New venture survival: Ignorance, external shocks, and risk reduction strategies. Journal of Business Venturing, 15, 393-410

Shin, J., \& Kim, S. K. (2019). The egocentrism of entrepreneurs: Bias in comparative judgments. Entrepreneurship Research Journal. https://doi.org/10.1515/erj-2017-0100

Soto, V. G. (2008). El stock de capital industrial medido a través de la relación inversión-empleo: Estimaciones para los estados mexicanos. Ensayos Revista De Economía, 27(1), 53-80.

Soto-Simeone, A., Sirén, C., \& Antretter, T. (2021). The role of skill versus luck in new venture survival. International Journal of Management Reviews, 23(4), 549-556. https://doi.org/10.1111/ijmr.12262

Spulber, D. F. (2014). The Innovative Entrepreneur. Cambridge University Press. https://doi.org/10.1017/CBO9781107239012

Strotmann, H. (2007). Entrepreneurial survival. Small Business Economics, 28, 84-101.

Su, Z., \& Wang, D. (2018). Entrepreneurial orientation, control systems, and new venture performance: A dominant logic perspective. Entrepreneurship Research Journal. https://doi.org/10.1515/erj-2017-0123

Ucbasaran, D., Westhead, P., \& Wright, M. (2001). The focus of entrepreneurial re-search: Contextual and process issues. Entrepreneurship Theory and Practice, 25(4), 57-80.

Van Praag, M., \& Versloot, P. H. (2008). The economic benefits and costs of entrepreneurship: A review of the research. Foundations and Trends in Entrepreneurship, 4(2), 65-154.

Varona, L., Gismera, L., \& Gimeno, R. (2014). Supervivencia de las empresas según indicadores empresariales. Modelo lineal mixto con datos de panel, período 2004 al 2008, caso de España. Working Papers 2014-13, Peruvian Economic Association. Retrieved from: https://ideas.repec.org/p/apc/wpaper/2014-013.html

Vergiú, J., \& Bendezú, C. (2007). Los indicadores financieros y el valor económico agregado (EVA) en la creación de valor. Industrial Data. https://doi.org/10.15381/idata.v10i1.6220

Viedma, J. M. (1992). La excelencia empresarial. McGraw Hill.

Weller, J. (2006). Inserción laboral de jóvenes: Expectativas, demanda laboral y trayectorias. Boletín RedEtis, 5, 1-6.

Wernerfelt, B., \& Montgomery, C. A. (1988). Tobin's Q and the importance of focus in firm performance. The American Economic Review, 78(1), 246-250.

Westhead, P., \& Cowling, M. (1995). Employment change in independent owner-managed high-technology firms in Great Britain. Small Business Economics, 7(2), 111-140.

Wijewardena, H., \& Cooray, S. (1995). Determinants of growth in small Japanese manufacturing firms: Survey evidence from Kobe. Journal of Small Business Management, 33(4), 87-92.

Woods, C., Yu, H., \& Huang, H. (2020). Predicting the success of entrepreneurial campaigns in crowdfunding: a spatiotemporal approach. Journal of Innovation and Entrepreneurship, 9, 13. https://doi.org/10.1186/s13731-020-00122-8

Zhai, Q., Su, J., Ye, M., \& Xu, Y. (2019). How do institutions relate to entrepreneurship: An integrative model. Entrepreneurship Research Journal. https://doi.org/10.1515/erj-2017-0001

\section{Publisher's Note}

Springer Nature remains neutral with regard to jurisdictional claims in published maps and institutional affiliations. 